\title{
LONGEVITY OF SPERMATOZOA IN THE REPRODUCTIVE TRACT OF THE BITCH
}

\author{
R. L. DOAK, ${ }^{*}$ ALLEN HALL $\dagger$ AND H. E. DALE \\ Veterinary Physiology and Pharmacology, School of Veterinary Medicine, \\ University of Missouri, Columbia, Missouri
}

(Received 20th December 1965, revised 16th May 1966)

\begin{abstract}
Summary. Survival of spermatozoa in the reproductive tract of the bitch was studied by examination of the female genitalia at measured intervals after copulation. Motile spermatozoa were found in the lumen of the uterus in undiminished concentrations for 4 to 6 days after copulation; numbers progressively declined but motile spermatozoa were observed as late as $268 \mathrm{hr}$ after copulation. Clusters of spermatozoa were observed in a high percentage of the uterine glands. The disappearance of spermatozoa was associated with the onset of metoestrus, not with time in the uterus. Bitches bred late in oestrus and examined in metroestrus had few spermatozoa compared with bitches examined in oestrus at a comparable time after copulation. Large numbers of spermatozoa were never found in the oviducts or ovarian bursae; they were consistently found here between 20 and $40 \mathrm{hr}$ after copulation, a single observation showed spermatozoa in the oviducts at 168 hours. Tubal ova were recovered from eight bitches in metoestrus, in five cleavage had begun; tubal ova were recovered from four bitches in oestrus, none had undergone cleavage. Examination of the ovaries indicated that ovulation most commonly occurred within $48 \mathrm{hr}$ after the onset of oestrus.
\end{abstract}

\section{INTRODUCTION}

The time of survival of spermatozoa in the reproductive tract of the female depends on a variety of factors, and differs between species. It is likely that qualitatively those criteria which determine motility and fertility are similar in all species, but the quantitative and temporal relationships between these factors do differ from one species to another and are responsible for characteristic survival times. (Burkhardt, 1949; Laing, 1945; Noyes \& Thibault, 1962; Olds \& VanDemark, 1957; and Quinlan, Mare \& Roux, 1933).

Detailed information about reproduction in the dog is scanty, but common knowledge indicates several features including prolonged oestrus and prooestrus, the characteristic bleeding and the possibility of spontaneous pseudopregnancy. Although spermatozoa have been observed in the anterior part of

* Present address: Department of Pathology, School of Veterinary Medicine, Washington State University, Pullman, Washington, U.S.A.

† Present address: Radiation Pathology Branch, Armed Forces Institute of Pathology, Washington, D.C. 20305, U.S.A. 
the tract shortly after copulation (Evans, 1933) and there is a single report of motile spermatozoa recovered from the bitch $84 \mathrm{hr}$ after breeding (Griffiths \& Amoroso, 1939), sperm survival in the reproductive tract of the bitch has not been studied systematically.

This investigation was undertaken primarily to measure how long motile spermatozoa could be recovered from the reproductive tract of the bitch after copulation; the investigation incidentally provided an opportunity to study the distribution of spermatozoa in the reproductive tract of the bitch and to evaluate the effect of time in the uterus per se upon the disappearance of spermatozoa.

\section{MATERIALS AND METHODS}

A total of fifty-four mongrel bitches was studied during an 18-month period; they ranged in age from 6 months to 5 years, from 20 to $45 \mathrm{lb}$ in weight. Five male dogs were used for mating; these were selected for compatible size, for libido and for sustained ability to produce high quality semen. All dogs were vaccinated for distemper-hepatitis and examined and treated for parasitism; they were routinely examined for signs of disease. The dogs were maintained in groups of three or four in outdoor concrete runs with shelter from wind and rain. Drinking water was available at all times; they were fed a ration of commercial dog food supplemented with vegetable oil, vitamins and meat.

All bitches were observed daily for signs of pro-oestrus. When genital swelling or vaginal discharge was apparent, the bitch was placed in an isolated run to which one of the male dogs was admitted for $1 \mathrm{hr}$ each day. The time and date of copulation were noted; the male was removed as soon as he was unlocked, the bitch then remained in the isolated run for the selected interval.

At the time of observation a lethal over-dose of pentobarbital sodium was given intravenously to the bitch. The reproductive tract was removed through a ventral mid-line incision; haemostats were applied to the uterotubal junction, and the entire tract was immersed in Ringer-Locke's solution at $39^{\circ} \mathrm{C}$. An immediate examination was made for motile spermatozoa; slides and tissue blocks were prepared for staining and later examination.

The search for motile spermatozoa involved a flushing and a moist impression technique. Flushing was done with Ringer-Locke's solution at $39^{\circ} \mathrm{C}$. Approximately $0.5 \mathrm{ml}$ was injected into each ovarian bursa which was then gently but thoroughly massaged; the fluid was then withdrawn with a pipette and placed on a warm slide. Approximately $1.0 \mathrm{ml}$ was used to flush each oviduct; the fluid was injected into the ovarian end of the oviduct with a 26 gauge needle and was collected from the uterine end of the oviduct on warm glass slides. All flushings were examined immediately; selected slides were then dried and stained with Delafield's haematoxylin.

Moist impressions were made at three levels in each uterine horn, from the body of the uterus and from the cervix. The general procedure was to cut across the structure with a pair of scissors, then to strip out lumen contents with thumb and forefinger. Ordinarily no more than a single drop of fluid was obtained in this manner and even this frequently necessitated the application of consider- 
able pressure. When not contaminated with blood, the fluid so expressed was water clear; it was impressed on a warm glass slide, mixed with a single drop of warm Ringer-Locke's solution and then examined immediately. When motile spermatozoa were not seen, selected slides were dried and stained with Delafield's haematoxylin for more detailed examination.

Examination for motile spermatozoa was done under low power $(100 \times)$. The fluid withdrawn from the bursa, or that expressed from the lumen of the uterus, was mixed with a drop of Ringer-Locke's solution and covered with a cover-slip; the slide was kept on an electric warming device during the examination. An estimate was made of the average number of spermatozoa/low-power field, and based on this estimate concentration was graded on an arbitrary scale from 1 to 5 (see Table 1 ).

Vaginal exfoliative cytology was used to identify the stage of the reproductive cycle in all bitches at the time of slaughter. This technique was also used to estimate the onset of oestrus in the few bitches bred late in oestrus rather than at the time of first acceptance.

After the search for motile spermatozoa and after gross examination, the entire tract was fixed in Zenker's solution. Tissue blocks were subsequently obtained from the upper, middle and lower portions of the oviduct and uterine horns, from the body of the uterus and from the cervix; a total of fourteen blocks from each reproductive tract. In addition the ovaries were sectioned so that the structures detected grossly could be examined microscopically. A total of twelve to fifteen serial sections was cut from each tissue block and then stained with haematoxylin and eosin pending microscopic examination.

\section{RESULTS AND DISCUSSION}

Early in the course of the investigation it became obvious that although large numbers of motile spermatozoa could be found in the uterus for extended periods after copulation, they were found in the bursae and oviducts much less frequently and in considerably smaller numbers. Also, it was soon apparent that, at any given interval after copulation, a bitch examined in metoestrus had a much lower concentration of spermatozoa in the uterus than a bitch examined in oestrus. The data were separated accordingly.

Table 1 shows the concentration of spermatozoa found in the reproductive tract of bitches examined in oestrus. For approximately 6 days after copulation motile spermatozoa were found in high concentration in all parts of the uterus. The number was noticeably diminished after this time, but motile spermatozoa were found as long as 11 days ( $268 \mathrm{hr}$ ) after copulation. Since it was only the exceptional bitch that would stay in oestrus longer than 8 days, a limited number of observations were possible at such extended intervals. These few instances of prolonged survival, however, together with the essentially undiminished concentration found in all bitches examined before the 6th day after copulation would seem to indicate that a bitch bred on the 1st day of oestrus will have motile spermatozoa in the uterus for the duration of the average oestrous period, 7 days. Furthermore, it is quite possible that a bitch bred on the 1st day of oestrus will have fertile spermatozoa in the uterus for most of the oestrous 
period. It has been observed in several other species that the fertile life of spermatozoa is approximately $50 \%$ of the motile life (Hammond \& Asdell,

TABLE 1

CONCENTRATION OF SPERMATOZOA IN THE REPRODUCTIVE TRACT OF BITCHES BRED THE IST DAY OF OESTRUS AND EXAMINED AT VARIOUS INTERVALS DURING OESTRUS

\begin{tabular}{|c|c|c|c|c|c|c|}
\hline \multirow[b]{2}{*}{$\begin{array}{l}\text { Hours after } \\
\text { copulation }\end{array}$} & \multicolumn{2}{|c|}{ Uterus } & \multicolumn{2}{|c|}{ Oviducts } & \multicolumn{2}{|c|}{ Bursae } \\
\hline & $\begin{array}{l}\text { Concentration } \\
\text { by moist } \\
\text { impression } \\
\text { or D's } H .^{*}\end{array}$ & $\begin{array}{l}\text { Percent of } \\
\text { uterine glands } \\
\text { with sperm; } \\
\text { mean of all } \\
\text { sections }\end{array}$ & Direct & $\begin{array}{c}D \text { 's } H .^{*} \\
\text { stain }\end{array}$ & Direct & $\begin{array}{c}D^{\prime} s H . * \\
\text { stain }\end{array}$ \\
\hline $\begin{array}{r}0 \cdot 25 \\
1 \cdot 0 \\
4 \cdot 0 \\
6 \cdot 0 \\
6 \cdot 5 \\
15 \cdot 0 \\
20 \cdot 0 \\
24 \cdot 0 \\
24 \cdot 0 \\
24 \cdot 5 \\
30 \cdot 0 \\
40 \cdot 0 \\
48 \cdot 0 \\
70 \cdot 5 \\
72 \cdot 0 \\
91 \cdot 0 \\
93 \cdot 0 \\
95 \cdot 0 \\
95 \cdot 0 \\
102 \cdot 0 \\
119 \cdot 0 \\
119 \cdot 0 \\
135 \cdot 0 \\
144 \cdot 0 \\
144 \cdot 0 \\
163 \cdot 0 \\
165 \cdot 0 \\
167 \cdot 0 \\
168 \cdot 0 \\
190 \cdot 0 \\
192 \cdot 0 \\
192 \cdot 5 \\
198 \cdot 0 \\
205 \cdot 0 \\
210 \cdot 5 \\
215 \cdot 0 \\
219 \cdot 0 \\
235 \cdot 0 \\
242 \cdot 0 \\
268 \cdot 0\end{array}$ & 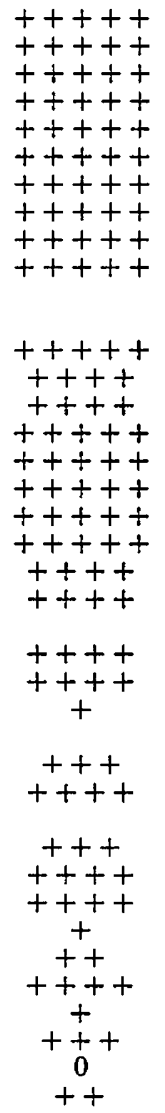 & $\begin{array}{r}56.8 \\
28.5 \\
29.0 \\
8.3 \\
44.8 \\
33.5 \\
7.5 \\
29.5 \\
34.0 \\
\\
25.8 \\
12.0 \\
0.0 \\
\\
42.5 \\
15.5 \\
\\
0.0 \\
0.0 \\
30.3 \\
2.0 \\
1.0 \\
21.8 \\
0.0 \\
0.0 \\
0.0 \\
0.0\end{array}$ & $\begin{array}{c}+ \\
+ \\
0 \\
+ \\
0 \\
0 \\
+ \\
+ \\
+ \\
+ \\
+ \\
+ \\
0 \\
+ \\
0 \\
0 \\
0 \\
0 \\
\\
0 \\
0 \\
+ \\
0 \\
0 \\
0 \\
0 \\
0 \\
0 \\
0 \\
0 \\
0 \\
0 \\
0 \\
0 \\
0 \\
0 \\
0 \\
0 \\
0 \\
0\end{array}$ & $\begin{array}{c}0 \\
0 \\
+++ \\
+++ \\
\begin{array}{c}++ \\
+ \\
++ \\
0 \\
0\end{array}\end{array}$ & $\begin{array}{l}0 \\
0 \\
+ \\
0 \\
0 \\
0 \\
0 \\
\\
0 \\
0 \\
\\
0 \\
0 \\
\\
0 \\
0 \\
0 \\
\\
0 \\
0 \\
\\
0 \\
0 \\
0 \\
0\end{array}$ & $\begin{array}{r}0 \\
+\end{array}$ \\
\hline
\end{tabular}

$0=$ none found; $+=1$ to 5 spermatozoa; $++=5$ to 25 spermatozoa; $++t=25$ to 100 spermatozoa; $++++=100$ to 500 spermatozoa; $+++++=500$ or more spermatozoa.

* Delafield's haematoxylin.

1927; Merton, 1938-39; and Soderwall \& Young, 1940); if this is also true for the dog and if spermatozoa in the uterus potentially retain motility for 11 days, then the fertile life of these spermatozoa would be in excess of 5 days. 
Examination of the stained sections in general confirmed the results found by flushing and by moist impression; however, in a few instances spermatozoa were found by these techniques but were not seen in the fixed sections, presumably because they had been washed off or destroyed in the staining process. The converse was not true; so that in our experience examination of the fresh specimens was the preferable technique to detect spermatozoa in the uterus.

Examination of the stained sections also revealed the rather unexpected fact that an appreciable number of uterine glands contained spermatozoa. Representative sections are shown in Pl. 1, Figs. 1 to 5. Typically, spermatozoa in the glands, like many of those in the lumen of the uterus, were clumped together with heads arranged in parallel rows around some central mass. These clumps were most frequently found in the neck of the uterine glands, less frequently at the base of the gland. Glands in all parts of the uterus contained spermatozoa; for the first $24 \mathrm{hr}$ after copulation the percentage of glands containing sperma-

TABLE 2

DISTRIBUTION OF SPERMATOZOA IN UTERINE GLANDS OF BITCHES EXAMINED IN OESTRUS AFTER COPULATION ON THE IST DAY OF OESTRUS

\begin{tabular}{|c|c|c|c|c|c|}
\hline \multirow{2}{*}{$\begin{array}{l}\text { Days after } \\
\text { copulation }\end{array}$} & \multicolumn{5}{|c|}{ Percentage of glands with spermatozoa } \\
\hline & $\begin{array}{l}\text { Upper } \\
\text { horn }\end{array}$ & $\begin{array}{l}\text { Middle } \\
\text { horn* }\end{array}$ & $\begin{array}{l}\text { Lower } \\
\text { horn* }\end{array}$ & Body & Cervix \\
\hline $\begin{array}{l}0 \text { to } 1 \\
\text { ( } 8 \text { bitches) }\end{array}$ & $35 \cdot 3$ & $40 \cdot 0$ & $44 \cdot 5$ & $47 \cdot 6$ & $37 \cdot 0$ \\
\hline $\begin{array}{l}2 \text { to } 3 \\
\text { ( } 6 \text { bitches) }\end{array}$ & $34 \cdot 0$ & $35 \cdot 2$ & $30 \cdot 3$ & $29 \cdot 3$ & $7 \cdot 3$ \\
\hline $\begin{array}{l}4 \text { to } 6 \\
\text { (4 bitches) }\end{array}$ & $30 \cdot 8$ & $28 \cdot 5$ & $29 \cdot 0$ & $21 \cdot 5$ & $2 \cdot 0$ \\
\hline $\begin{array}{l}7 \text { to } 8 \\
\text { (7 bitches) }\end{array}$ & $13 \cdot 0$ & $11 \cdot 4$ & $8 \cdot 7$ & $7 \cdot 7$ & $0 \cdot 0$ \\
\hline $\begin{array}{l}9 \text { to } 11 \\
\text { ( } 3 \text { bitches) }\end{array}$ & $0 \cdot 0$ & 0.0 & 0.0 & 0.0 & $0 \cdot 0$ \\
\hline
\end{tabular}

* Average of right and left.

tozoa was higher in the body of the uterus than in the horns, thereafter the percentage of glands with spermatozoa was higher in the horns than in the body (Table 2). Differences were not great, however. Spermatozoa have been described in similar locations in other species (Bobr, Lorenz \& Ogasawara, 1962, 1964; Fox, 1956, 1963; Kohlbrugge, 1912; Ludwig \& Rahn, 1943) but not previously in the bitch.

Three of the four bitches examined after $215 \mathrm{hr}$ had motile spermatozoa in the lumen of the uterus; none had spermatozoa in the lumen of the glands. The possibility is suggested that spermatozoa in the glands replace those in the lumen as they are lost by migration and attrition.

Bitches examined after the onset of metoestrus had very few spermatozoa either in the lumen of the uterus or in the uterine glands (Table 3). Concentrations at any particular time after copulation were so much lower than in bitches examined in oestrus that it was concluded that it was not time in the uterus 
as such but rather some other factor which was responsible for their disappearance. Accordingly, four bitches were bred late in oestrus and then examined on the 2nd day of metoestrus. Concentrations are shown in the lower part of Table 3. Bitches examined in oestrus at comparable times after copulation on the 1st day of oestrus had large numbers of motile spermatozoa in the lumen of the uterus and spermatozoa in many of the uterine glands. The low concentration observed in these four bitches provides additional evidence that it is not only time but some other factor which mitigates survival of spermatozoa after the onset of metoestrus.

The number of spermatozoa found in the oviducts was considerably lower

TABLE 3

CONCENTRATION OF SPERMATOZOA IN THE UTERUS OF BITCHES BRED DURING OESTRUS AND EXAMINED IN METOESTRUS

\begin{tabular}{|c|c|c|}
\hline Hours after copulation & $\begin{array}{l}\text { Concentration by } \\
\text { moist impression } \\
\text { or } D^{\prime} s H .\end{array}$ & $\begin{array}{l}\text { Percentage of uterine } \\
\text { glands with sperm; } \\
\text { mean of all sections }\end{array}$ \\
\hline $\begin{array}{c}\text { Bred on 1st day of oestrus } \\
118 \\
135 \\
185 \\
190 \\
192 \\
192 \\
197 \\
214 \\
223 \\
232 \\
238 \\
240 \\
241 \\
264 \\
264 \\
286\end{array}$ & $\begin{array}{c}0 \\
+ \\
++ \\
+ \\
+ \\
+ \\
0 \\
0 \\
++ \\
0 \\
+ \\
++ \\
++ \\
0 \\
++ \\
0\end{array}$ & $\begin{array}{l}0.0 \\
3 \cdot 5 \\
1.3 \\
1.0 \\
0.0 \\
0 \cdot 0 \\
0 \cdot 0 \\
0.5 \\
0 \cdot 0 \\
0 \cdot 0 \\
0 \cdot 0 \\
0.0 \\
0.0 \\
0.0 \\
0.0 \\
0.0\end{array}$ \\
\hline $\begin{array}{c}\text { Bred on 6th day of oestrus } \\
44 \cdot 0 \\
54 \cdot 5 \\
79 \cdot 0 \\
96 \cdot 0\end{array}$ & $\begin{array}{l}+ \\
+ \\
+ \\
0\end{array}$ & $\begin{array}{l}0.0 \\
0.0 \\
0.0 \\
0.0\end{array}$ \\
\hline
\end{tabular}

See Table 1 for definitions.

than the number found in the uterus (Table 1); frequently they could not be found at all, despite the fact that they were present in the uterus in high concentration. Spermatozoa were found even less frequently and in smaller numbers in the ovarian bursae. The size and nature of these structures necessitated a flushing technique in contrast to the stripping technique used on the uterus and this, in part, may account for the difference in concentration. The paucity of spermatozoa at the site of fertilization is, however, consistent with previous reports (Austin \& Bishop, 1957; Evans, 1933; and Leonard \& Perlman, 1949). No spermatozoa were found in the oviducts or bursae of bitches examined in metoestrus.

Limited observations made incidentally to this study suggest that while 
PLATE 1

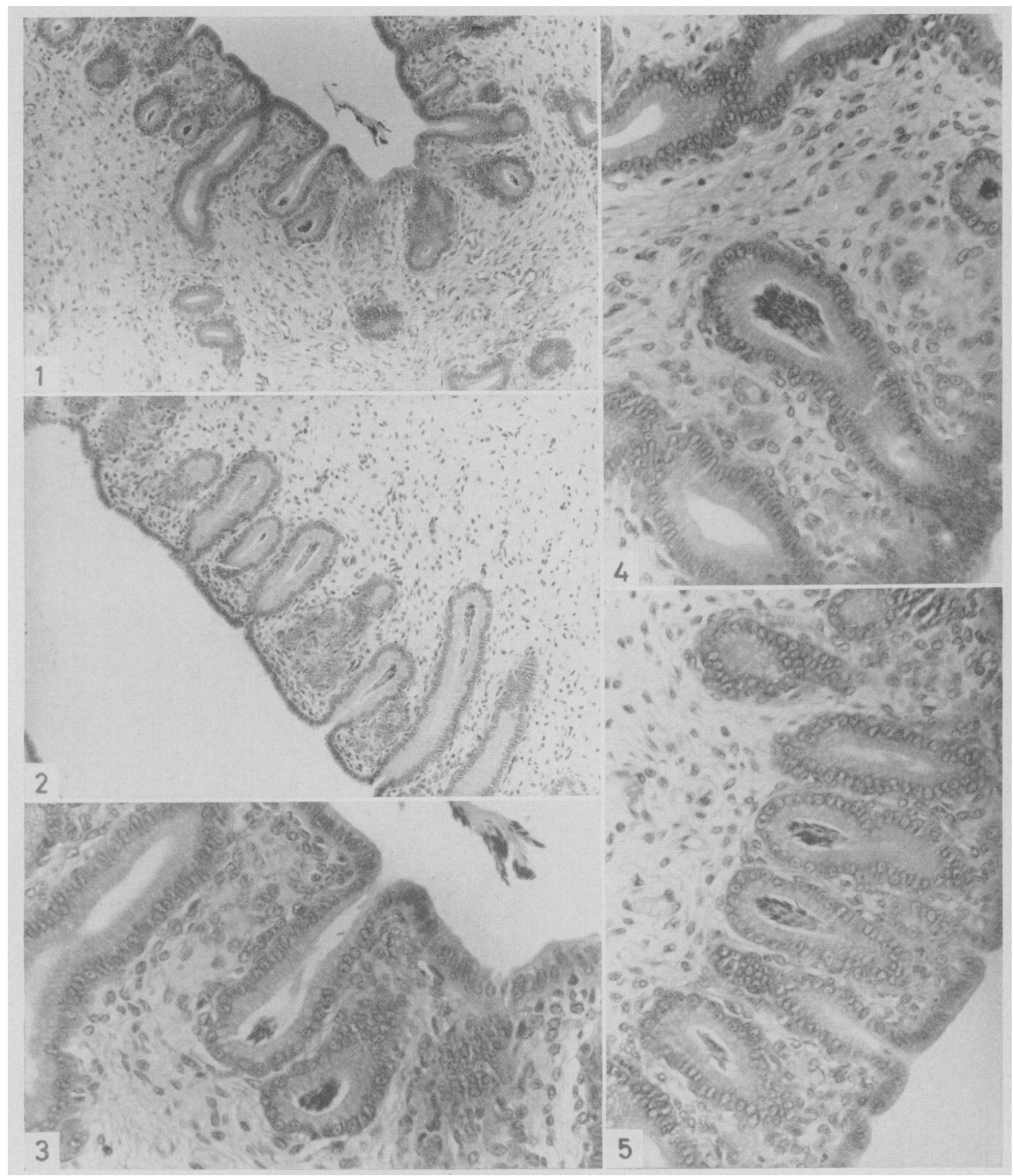

Fici. 1. Cross-section of right uterine horn. Bitch examined in oestrus $119 \mathrm{hr}$ after copulation. Clumps of spermatozoa are visible in the lumen of the uterus and in the necks of the uterinc glands. $\times 140$.

Fig. 2. Left uterine horn of bitch examined $48 \mathrm{hr}$ after copulation; clumps of spermatozoa are visible in the necks of a high percentage of the uterine glands. $\times 140$.

Fic. 3. Same section as Fig. 1. Both in the lumen and in the gland sperm heads seem to be clumped around a central mass. $\times 365$.

Fig. 4. From same section as Fig. 1. Spermatozoa in neck of gland. Parallel arrangement of heads is typical. $\times 365$.

Fig. 5. From same section as Fig. 1. Sperm heads are not necessarily in contact with cach other. $\times 365$.

(Facing p. 56) 
ovulation occurs early in oestrus, cleavage of the zygote does not begin until after the onset of metoestrus. As indicated in Table 4 ova were recovered from four bitches examined in oestrus, none had undergone cleavage, ova were

TABLE 4

RECOVERY OF OVA

\begin{tabular}{|c|c|c|c|c|}
\hline $\begin{array}{l}\text { Hours after } \\
\text { copulation }\end{array}$ & $\begin{array}{l}\text { No. of ova } \\
\text { recovered }\end{array}$ & $\begin{array}{c}\text { No. of } \\
\text { corpora lutea }\end{array}$ & Recovered from & Cleavage \\
\hline \begin{tabular}{ll}
185 & \\
192 & \\
$192 \cdot 5$ & $\mathrm{O}^{*}$ \\
219 & $\mathrm{O}^{*}$ \\
223 & \\
235 & $\mathrm{O}^{*}$ \\
240 & \\
241 & \\
264 & \\
268 & $\mathrm{O}^{*}$ \\
\multicolumn{2}{l}{ Metoestrus } \\
\multicolumn{2}{l}{ Metoestrus }
\end{tabular} & $\begin{array}{r}12 \\
2 \\
5 \\
3 \\
2 \\
4 \\
1 \\
8 \\
1 \\
4 \\
9 \\
7\end{array}$ & $\begin{array}{r}12 \\
4 \\
9 \\
5 \\
5 \\
6 \\
6 \\
12 \\
9 \\
7 \\
10 \\
7\end{array}$ & $\begin{array}{c}\text { Oviducts } \\
\text { Oviducts } \\
\text { Oviducts } \\
\text { Oviducts } \\
\text { Oviducts } \\
\text { Oviducts } \\
\text { Upper left horn } \\
\text { Oviducts } \\
\text { Upper right horn } \\
\text { Oviducts } \\
\text { Oviducts } \\
\text { Oviducts }\end{array}$ & $\begin{array}{c}\text { None } \\
\text { None } \\
\text { None } \\
\text { None } \\
\text { None } \\
\text { None } \\
>32 \text {-cell stage } \\
\text { 8-cell stage } \\
>32 \text {-cell stage } \\
\text { None } \\
8 \text { to } 16 \text {-cell stage } \\
16 \text { to } 32 \text {-cell stage }\end{array}$ \\
\hline
\end{tabular}

TABLE 5

OVARIAN AGTIVITY DURING OESTRUS

\begin{tabular}{c|c|c}
\hline Hours after copulation & Follicles & Corpora lutea \\
\cline { 2 - 3 } $66 \cdot 5$ & 4 & 8 \\
20 & 12 & 0 \\
48 & 5 & 0 \\
70.5 & 0 & 7 \\
93 & 0 & 9 \\
102 & 0 & 5 \\
135 & 0 & 10 \\
163 & 1 & 11 \\
185 & 1 & 12 \\
190 & 1 & 6 \\
192 & 0 & 4 \\
$192 \cdot 5$ & 0 & 9 \\
210.5 & 1 & 5 \\
215 & 0 & 7 \\
219 & 1 & 5 \\
223 & 0 & 5 \\
235 & 0 & 6 \\
240 & 0 & 6 \\
241 & 0 & 12 \\
242 & 0 & 6 \\
264 & 0 & 9 \\
268 & 0 & 7 \\
Metoestrus* & 0 & 11 \\
Metoestrus* & 0 & 10 \\
Metoestrus* & 0 & 8 \\
Metoestrus* & 0 & 11 \\
\hline
\end{tabular}

* Hours after copulation not known.

recovered from eight bitches in metoestrus, ova from five had undergone cleavage. Apparently the destruction of uterine spermatozoa and division of the fertilized ovum occur at about the same time in the bitch. 
The structures detected by gross examination on the surface of the ovary were tentatively identified as ruptured or unruptured follicles; the ovary was subsequently sectioned so that each of these structures could be examined microscopically. The results, Table 5, show that $48 \mathrm{hr}$ after the onset of oestrus few unruptured follicles are found on the surface of the ovary. Ovulation early in oestrus is at first glance incongruous with prolonged survival of spermatozoa; however, at the time of ovulation the ovum of the bitch is not mature, and fertilization awaits extrusion of the second polar body.

\section{ACKNOWLEDGMENT}

This study was supported in part by a grant from the Morris Animal Foundation.

\section{REFERENCES}

Austin, C. R. \& Brshop, M. W. H. (1957) Preliminaries to fertilization in mammals. Biol. Rev. 32, 296.

Bobr, L. W., Lorenz, F. W. \& Ogasawara, F. X. (1962) The role of the uterovaginal junction in storage of cock spermatozoa. (Abstract). Poult. Sci. 41, 1628.

Bobr, L. W., Lorenz, F. W. \& Ogasawara, F. X. (1964) Distribution of spermatozoa in the oviduct and fertility in domestic birds. I. Residence sites of spermatozoa in fowl oviducts. 7. Reprod. Fert. 8, 39.

Burkhard, J. (1949) Sperm survival in the genital tract of the mare. F. agric. Sci. 39, 201.

Evans, E. I. (1933) The transport of spermatozoa in the dog. Am. F. Physiol. 105, 287.

Fox, W. (1956) Seminal receptacles of snakes. Anat. Rec. 124, 519.

Fox, W. (1963) Special tubules for sperm storage in female lizards. Nature, Lond. 198, 500.

Griffiths, W. F. B. \& Amoroso, E. C. (1939) Prooestrus, oestrus, ovulation, and mating in the greyhound bitch. Vet. Rec. 51, 1279.

Hammond, J. \& Asdell, S. A. (1927) The vitality of the spermatozoa in the male and female reproductive tracts. Br. J. exp. Biol. 4, 155.

Kohlbrugge, J. H. F. (1912) Die Verbreiten der Spermatozoiden im weiblichen Korper und im befruchteten Ei. Arch. EntwMech. Org. 35, 166.

LaING, J. A. (1945) Observations on the survival time of the spermatozoa in the genital tract of the cow and its relation to fertility. F. agric. Sci. 35, 72.

Leonard, S. L. \& Perlman, P. O. (1949) Conditions effecting the passage of spermatozoa through the utero-tubal junction of the rat. Anat. Rec. 104, 89.

Ludwig, M. \& RAHN, H. (1943) Sperm storage and copulatory adjustment in the prairie rattlesnake. Copeia, 15.

Merton, H. (1938-39) Studies of reproduction in the albino mouse. III. The duration of live spermatozoa in the female reproductive tract. Proc. R. Soc. Edinb. 58-59, 207.

Noyes, R. W. \& Thibault, C. (1962) Endocrine factors in the survival of spermatozoa in the female reproductive tract. Fert. Steril. 13, 346.

Olds, D. \& VANDEMARK, N. L. (1957) The behavior of spermatozoa in luminal fluids of bovine female genitalia. Am. F. vet. Res. 18, 603.

Quinlan, J., Mare, G. S. \& Roux, L. L. (1933) A study of the duration of motility of spermatozoa in the different divisions of the reproductive tract of the merino ewe. Oonderstepoort 7. vet. Sci. Anim. Ind. $1,135$.

Soderwall, A. L. \& Young, W. C. (1940) The effect of aging in the female genital tract on the fertilizing capacity of guinea-pig spermatozoa. Anat. Rec. 78, 19. 